\title{
Profiling soil free-living nematodes in the Namib Desert, Namibia
}

\author{
Eugene MARAIS ${ }^{1}$, Gillian MAGGS-KÖLLING ${ }^{1}$, Chen SHERMAN ${ }^{2}$, Tirza DONIGER ${ }^{2}$, LIU \\ Rentao $^{3}$, Binu M TRIPATHI ${ }^{4}$, Yosef STEINBERGER ${ }^{2 *}$ \\ ${ }^{1}$ Gobabeb Research and Training Centre, Walvis Bay, Gobabeb 953, Namibia; \\ ${ }^{2}$ The Mina \& Everard Goodman Faculty of Life Sciences Bar-Ilan University, Ramat-Gan 5290002, Israel; \\ ${ }^{3}$ Key Laboratory for Restoration and Reconstruction of Degraded Ecosystem in Northwestern China of Ministry of Education, \\ Ningxia University, Yinchuan 750021, China; \\ ${ }^{4}$ Korea Polar Research Institute, Incheon 21990, Korea
}

\begin{abstract}
Functional structure and diversity of soil free-living nematodes in a desert environment depend on plant gender and sampling site. The objective of this study was to compare the composition, abundance and tropic group of soil free-living nematodes in the upper $0-10 \mathrm{~cm}$ soil layer under the male and female Acanthosicyos horridus Welw. ex Hook. f. plants and in the inter-shrub open areas (control) in the Namib Desert, Namibia in April 2015. Soil moisture, organic matter (OM) and $\mathrm{pH}$ was also analyzed. Free-living nematodes were extracted from $100 \mathrm{~g}$ soil using the Baermann funnel procedure, and total number of nematodes was counted under a microscope. Community composition and diversity of soil free-living nematodes were analyzed using $18 \mathrm{~S}$ rDNA sequences. Results indicated that a total of 67 groups, including 64 species, 2 genera and 1 family were identified. Feeding behavior of 58 species were identified as follows: 15 bacteria-feeding species, 12 fungi-feeding species, 10 plant-parasite species, 5 omnivorous-predator species, 8 animal-parasite species, 5 invertebrate-parasite species and 3 non-free-living nematodes, known as marine species. Moreover, soil free-living nematodes were found to be affected by sampling locations and plant gender, and community composition and density of these nematodes were strongly influenced by soil OM content. Result confirmed that spatial location and plant cover were main factors influencing the diversity of soil free-living nematodes. Moreover, molecular tools were found to be very useful in defining the richness of soil non-free-living nematodes. In conclusion, the results elucidated the importance of biotic variables in determining the composition and abundance of soil free-living nematodes in the Namib Desert, Namibia.
\end{abstract}

Keywords: plant gender; plant cover; nematodes; trophic group; diversity; $18 \mathrm{~S}$ rDNA

Citation: Eugene MARAIS, Gillian MAGGS-KÖLling, Chen SHERMAN, Tirza DONIGER, LIU Rentao, Binu M TRIPATHI, Yosef STEINBERGER. 2020. Profiling soil free-living nematodes in the Namib Desert, Namibia. Journal of Arid Land, 12(1): 130-143. https://doi.org/ 10.1007/s40333-019-0018-5

\section{Introduction}

The common feature unique to all deserts is water availability that influences substrate composition and structure (Whitford, 2002). In the desert ecosystem with a high temperature, soil moisture (SM) is unpredictable in time, space and amount. SM is critical for the biotic community, and enables it to fulfill its biological functions via adaptation to such arid environment (Crawford,

\footnotetext{
*Corresponding author: Yosef STEINBERGER (E-mail: yosef.steinberger@biu.ac.il)

Received 2018-06-27; revised 2019-05-27; accepted 2019-06-06

(C) Xinjiang Institute of Ecology and Geography, Chinese Academy of Sciences, Science Press and Springer-Verlag GmbH Germany, part of Springer Nature 2020
} 
1981; Evenari et al., 1982; Wardle, 2002; Whitford, 2002).

In the Namib Desert, one of the largest sandy deserts in the world (Laity, 2008), edaphic factors result in the aridity. Despite the relatively low amount of precipitation $(<200 \mathrm{~mm})$, soil substrate (deep layer of sandy soil) enhances water filtration and results in the lack of water availability in the upper soil layer. As a result, moisture level in the upper soil layer combined with the extreme fluctuation in temperature drive soil biota to develop an eco-physiological adaptation due to the unpredictability of food availability (Evenari et al., 1982; Steinberger et al., 1989; Whitford, 2002). Moreover, the Namib desert is also known as one of the six coastal fog deserts whose water balance is based on the inputs of fog and dew, in addition to the precipitation (Eckardt et al., 2013). These two additional sources of water play important roles in the above-ground biotic community (Seely et al., 2005) and are of great importance to the below-ground biotic community (soil microflora, microfauna and mesofauna) (Rodriguez-Zaragoza et al., 2005; Stomeo et al., 2012; Frossard et al., 2015). However, little is known about soil free-living nematodes and the mesofauna-plant cover interactions in this desert system.

Soil free-living nematodes are known to constitute the most abundant and diverse group of multicellular animals among soil biota (Lambshead, 2004). The phylum of soil free-living nematodes is estimated to contain over one million species inhabiting aquatic and terrestrial ecosystems. These nematodes play a wide range of ecosystem function and service through interactions with the other groups of organisms in soils or sediments. Moreover, their interactions with other biota are not limited to feeding on bacteria, fungi, plant cells and omnivores. They also feed on other nematodes, heterotrophic protists and arthropod hosts (Yeates et al., 1993; Yeates and King, 1997; Levi et al., 2012). The activity, density and diversity of soil free-living nematodes in natural environments were found to be strongly influenced by soil physical-chemical characteristics and food resources (Pen-Mouratov et al., 2004; Fitoussi et al., 2016). The abundance and diversity of bacteria-feeding and fungi-feeding nematodes in a desert are the basis of distribution of plant litter (Freckman and Mankau, 1977; Steinberger et al., 1988). Therefore, it is necessary to study the density and diversity of soil free-living nematodes of common plants in a desert system.

Acanthosicyos horridus Welw. ex Hook. f. is widely distributed in the Namib Desert (Berry, 2003). The male and female plants of $A$. horridus are equally distributed (Cloudsley-Thompson, 1996). Moreover, the female plants of A. horridus produces succulent melon fruits that might contribute the accumulation of organic matter in its microhabitat. The objective of this study was to examine the effects of male and female A. horridus plants in the Namib Desert on the composition, abundance and tropic group of soil free-living nematodes. We hypothesized that abiotic components, e.g., SM, organic matter (OM), soil $\mathrm{pH}$ and plant gender play important roles in the composition, abundance and trophic group of soil free-living nematodes.

\section{Study area and methods}

\subsection{Study area}

The Namib Desert is hyper-arid, which is known as a detritus-driven ecosystem in Namibia, Africa. The daily mean temperature ranges from $15^{\circ} \mathrm{C}$ to $55^{\circ} \mathrm{C}$ (Seely and Louw, 1980). The mean annual precipitation is $14.1 \mathrm{~mm}$. In addition, the annual input of fog equals to $69.2 \mathrm{~mm}$. The average number of precipitation is $59 \mathrm{~d}$, ranging from 45 to $138 \mathrm{~d}$ (Gobabeb Research and Training Center (GRTC) First Order Meteorological Station, Namibia). We collected soil samples in the early morning in order to avoid the heating and drying of dew. The vegetation in the Namib Desert is covered with sparsely grasses, such as Stipagrosti sabulicola and Stipagrostis gonastachys, Arthraerua leubnitziae, Zygophyllum stapfii and A. horridus (Louw and Seely, 1982). The perennial $A$. horridus plants that are totally leafless, attain a height of about $1.5 \mathrm{~m}$, and have deep roots that are able to reach underground water. The female plants produce spiny fruits in February and April, which are eaten by animals and collected by local residents as an important food source. 


\subsection{Soil sample collection}

Soil samples were collected from the following three sites along a 150-km distance: (1) Kuiseb Delta (hereinafter referred to as Delta) site $\left(23^{\circ} 06.968^{\prime} \mathrm{N}, 14^{\circ} 28.640\right.$ 'E; $26 \mathrm{~m}$ a.s.l.) is located in a green belt (1.5 km from the seashore of the Atlantic Ocean). The mean amount of precipitation is $99 \mathrm{~mm}$; (2) Gobabeb site $\left(23^{\circ} 05.903^{\prime} \mathrm{N}, 15^{\circ} 03.109^{\prime} \mathrm{E}\right.$; $418 \mathrm{~m}$ a.s.l.) is located in the vicinity of the Gobabeb Desert Research Station, about $60.0 \mathrm{~km}$ from the seashore of the Atlantic Ocean. The mean amount of precipitation ranges from 100 to $199 \mathrm{~mm}$; and (3) Far East (FE) sand dunes $\left(23^{\circ} 40.315^{\prime} \mathrm{N}, 15^{\circ} 39.251^{\prime} \mathrm{E} ; 872 \mathrm{~m}\right.$ a.s.1.) is located at a distance of $150.0 \mathrm{~km}$ from the seashore of the Atlantic Ocean, with the mean amount of precipitation ranging from 200 to $300 \mathrm{~mm}$.

\subsection{Soil analysis}

Three sampling sites are located at distances of 1.5, 60.0, and $150.0 \mathrm{~km}$ from the seashore of the Atlantic Ocean. Soil samples at each site were collected from the upper $0-10 \mathrm{~cm}(n=4)$ layer beneath the male and female $A$. horridus plants, and in the inter-shrub open areas as a control (total of 36 samples) in April 2015. Each soil sample was placed in an individual plastic bag and took back to laboratory.

SM (\%) content was gravimetrically determined by drying soil samples for $72 \mathrm{~h}$ at $105^{\circ} \mathrm{C}$. OM (\%) content was determined by igniting samples at $490^{\circ} \mathrm{C}$ for $8 \mathrm{~h}$. Soil $\mathrm{pH}$ was measured with a glass electrode using a 1:2 soil:water ratio. Bulk density $\left(\mathrm{BD}, \mathrm{g} / \mathrm{cm}^{3}\right)$ was determined as the weight of soil in a given volume. For the determination of soil water-holding capacity (WHC, \%), $100 \mathrm{~g}$ soil samples were flooded with tap water in a bottom-perforated vessel for $5 \mathrm{~min}$.

Soil free-living nematodes were extracted using the Baermann funnel procedure (Cairns, 1960), and total number of nematodes was counted under a microscope. The nematodes were transferred to an Eppendorf tube after being centrifuged for $10 \mathrm{~min}$ at $10,000 \mathrm{rpm}$ to reduce the amount of remaining water. The obtained pellets were placed at $-20^{\circ} \mathrm{C}$ until identification using molecular tools. DNA was extracted from the pellets using the PowerSoil DNA Isolation Kit (MO-BIO Laboratories, Inc., Carlsbad, USA). The eluted DNA was stored at $-20^{\circ} \mathrm{C}$ until it was used as a polymerase-chain-reaction (PCR) template. The $3^{\prime}$ end of the $18 \mathrm{~S}$ rDNA was amplified using primer pair NF1 (5'-GGT GGT GCA TGG CCG TTC TTA GTT-3') and 18Sr2b (5'-TAC AAA GGG CAG GGA CGT AAT-3') (Porazinska et al., 2009). Reactions were carried out at a 25.00- $\mu \mathrm{L}$ final volume including $15.75 \mu \mathrm{L}$ ultrapure water, $5.00 \mu \mathrm{L}$ buffer, $0.50 \mu \mathrm{L}$ dNTPs, $1.25 \mu \mathrm{L} \mathrm{F}$ primer, $1.25 \mu \mathrm{L}$ R primer, $0.25 \mu \mathrm{L}$ Phusion High Fidelity DNA Polymerase (100 U, $2 \mathrm{U} / \mu \mathrm{L}$, Thermo Scientific, USA) and $1.00 \mu \mathrm{L}$ DNA from each sample. Cycling was performed by Veriti 96-Well Thermal Cycler (Applied Biosystems, Carlsbad, California, USA). The PCR program involved a denaturation step of $30 \mathrm{~s}$ at $98^{\circ} \mathrm{C}$, a denaturation step of $10 \mathrm{~s}$ at $98^{\circ} \mathrm{C}$, an annealing step of $30 \mathrm{~s}$ at $56^{\circ} \mathrm{C}$, an extension step of $1.5 \mathrm{~min}$ at $72^{\circ} \mathrm{C}$ and a final extension step of $10.0 \mathrm{~min}$ at $72^{\circ} \mathrm{C}$. Steps 2-4 were repeated for 20 cycles. Each PCR product was diluted with ultrapure water 1:100, and underwent both vortex spinning and a second PCR amplification using F primer, with barcodes for each sample. A negative control was included in each amplification.

For 18S rDNA sequences, we carried out amplification using the forward primer barcode sequence NTF1 IT1-NTF1 IT37: 5'-CCA TCT CAT CCC TGC GTG TCT CCG ACT CAG CTA AGG TAA CGG TGG TGC ATG GCC GT-3', and the reverse primer sequence 18Sr2bIT: 5'-CCT CTC TAT GGG CAG TCG GTG ATT ACA AAG GGC AGG GAC GTA AT-3'. The PCR program involved a denaturation step of $3 \mathrm{~min}$ at $98^{\circ} \mathrm{C}$, a denaturation step of $30 \mathrm{~s}$ at $98^{\circ} \mathrm{C}$, an annealing step of $30 \mathrm{~s}$ at $55^{\circ} \mathrm{C}$, an extension step of $1 \mathrm{~min}$ at $72^{\circ} \mathrm{C}$ and a final extension step of $5 \mathrm{~min}$ at $72^{\circ} \mathrm{C}$. A $5 \mu \mathrm{L}$ portion of all PCR products, along with $1 \mathrm{~kb}$ DNA ladder (Thermo Scientific, USA) was electrophoresed in 1\% agarose gel (SeaKem, Lonza, Rockland, ME, USA) and stained with 1 $\mu \mathrm{L}$ GelStar. No PCR products were observed in the negative control, and the correct size of the positive band was observed. The remaining $20 \mu \mathrm{L}$ DNA of each sample were electrophoresed in $0.5 \%$ low-melt agarose (CSL-AG100), and stained with a $3-\mu \mathrm{L}$ gel. The GeneJET Kit (Thermo Scientific, USA) was used for the recovery and purification of DNA from low-melting agarose. 
After cutting the desired band length of DNA (400 bp), all DNA sample products underwent ion torrent sequencing of $18 \mathrm{~S}$ rDNA (Fitoussi et al., 2016).

We processed the recovered sequences of DNA in QIIME (Quantitative Insights into Microbial Ecology) version 1.7.0 (Caporaso et al., 2010a, b) using the pipeline for analyzing 18S rDNA sequence data. Default settings, along with UClust algorithm, were used for de novo selection of operational taxonomic units (OTUs) at $97 \%$ similarity. The SILVA 111 release was used as a reference for taxonomic assignments of OTUs (Yilmaz et al., 2014). Since the SILVA 111 database contained only an essential number of nematode reads, we sought to reclassify the reads assigned to Nematoda in the QIIME classification by the Basic Local Alignment Search Tool (BLAST) similarity analysis using a custom-made nematode $18 \mathrm{~S}$ rDNA sequences. The database enabled us to obtain a better insight into the community of nematodes. The R/Bioconductor Package Phyloseq version 1.16.2 was used to draw phylogenetic tree from the QIIME data. All measurements were assessed using data for OTUs with at least 5 reads in the overall dataset.

\subsection{Data analysis}

All data were subjected to statistical analysis of variance (ANOVA) using the SAS model (Duncan's multiple test and Pearson's coefficient), and were used to evaluate differences between separate means. ANOVA was followed by Tukey's HSD test to establish the significance of differences between plot areas using the statistical package Statistica 4.3 (StatSoft Inc., Tulsa, OK, USA). Differences obtained at level of $P<0.05$ were considered significant.

We used RDA to correlate the composition of soil free-living nematodes with environmental variables. Partial RDA were used to determine the effect of variable as covariable, that of soil water content with the remaining variables as covariables, that of WHC with the remaining variables as covariables, and that of conductivity (cond) with the remaining variables as covariables, etc. (Liu et al., 2012).

The data and Monte Carlo reduced model tests with 499 unrestricted permutations were used to statistically evaluate significance of the first canonical axis and all canonical axes combined. To meet requirements of the Monte Carlo reduced model test, we square-root-transformed the data of taxonomic group. DCA, RDA and partial RDA were carried out using CANOCO software for Windows 4.5 (Microcomputer Power, Ithaca, NY, USA).

\section{Results}

\subsection{Abiotic variables}

Mean values of different soil physical parameters at three sites and three locations, i.e., male and female A. horridus plants and the inter-shrub open areas as the control at each site are presented in Table 1.

SM contents were low and ranged from $0.24 \%$ at Delta to $0.49 \%$ at FE sand dunes. Significant difference in SM $(P<0.05)$ content at FE sand dunes was found. SM content in three locations at each site did not significantly differ (Table 1$)$.

OM contents ranged from $0.26 \%$ at FE sand dunes to $0.52 \%$ at Gobabeb site. OM content was significant $(P<0.05)$ higher at FE sand dunes than at the other two sites. No significant differences were found at the locations of Gobabeb and FE sand dunes, while at Delta, OM content beneath the male and female plants was significant $(P<0.05)$ higher than that of control. BD was significant $(P<0.05)$ higher at Gobabeb compared with the other two sites, while WHC was significant $(P<0.05)$ lower at Gobabeb. An attempt was made to determine the effects of male/female plants and control (i.e., three locations) at each site on soil physical-chemical characteristics (Table 1). For BD, significant $(P<0.05)$ differences, such as control $>$ female $>$ male, were found only at Delta. As for WHC, no significant differences were found at three locations of FE sand dunes, while WHC beneath the male A. horridus plants was significant $(P<0.05)$ higher than those of beneath the female A. horridus plants and control. 
Table 1 ANOVA results for soil physical-chemical characteristics at different sites and locations

\begin{tabular}{cccccc}
\hline Site & Location & SM $(\%)$ & OM $(\%)$ & BD $\left(\mathrm{g} / \mathrm{cm}^{3}\right)$ & WHC $(\%)$ \\
\hline \multirow{2}{*}{ Delta } & Cont. & $0.29 \pm 0.06^{\mathrm{a}}$ & $0.22 \pm 0.05^{\mathrm{b}}$ & $1.54 \pm 0.02^{\mathrm{a}}$ & $0.22 \pm 0.005^{\mathrm{c}}$ \\
& Fem. & $0.21 \pm 0.10^{\mathrm{a}}$ & $0.35 \pm 0.07^{\mathrm{a}}$ & $1.38 \pm 0.02^{\mathrm{b}}$ & $0.26 \pm 0.01^{\mathrm{b}}$ \\
& Male & $0.22 \pm 0.22^{\mathrm{a}}$ & $0.44 \pm 0.03^{\mathrm{a}}$ & $1.31 \pm 0.03^{\mathrm{c}}$ & $0.28 \pm 0.01^{\mathrm{a}}$ \\
& Mean & $0.24 \pm 0.13^{\mathrm{B}}$ & $0.33 \pm 0.10^{\mathrm{B}}$ & $1.41 \pm 0.10^{\mathrm{B}}$ & $0.25 \pm 0.02^{\mathrm{A}}$ \\
& Cont. & $0.24 \pm 0.04^{\mathrm{a}}$ & $0.53 \pm 0.02^{\mathrm{a}}$ & $1.51 \pm 0.02^{\mathrm{a}}$ & $0.21 \pm 0.005^{\mathrm{b}}$ \\
Gobabeb & Fem. & $0.21 \pm 0.09^{\mathrm{a}}$ & $0.45 \pm 0.04^{\mathrm{a}}$ & $1.51 \pm 0.04^{\mathrm{a}}$ & $0.23 \pm 0.01^{\mathrm{ab}}$ \\
& Male & $0.38 \pm 0.14^{\mathrm{a}}$ & $0.65 \pm 0.05^{\mathrm{a}}$ & $1.49 \pm 0.02^{\mathrm{a}}$ & $0.24 \pm 0.01^{\mathrm{a}}$ \\
& Mean & $0.26 \pm 0.10^{\mathrm{B}}$ & $0.52 \pm 0.08^{\mathrm{A}}$ & $1.46 \pm 0.14^{\mathrm{A}}$ & $0.22 \pm 0.01^{\mathrm{B}}$ \\
Far East (FE) & Cont. & $0.53 \pm 0.12^{\mathrm{a}}$ & $0.26 \pm 0.18^{\mathrm{a}}$ & $1.41 \pm 0.03^{\mathrm{a}}$ & $0.26 \pm 0.01^{\mathrm{a}}$ \\
sand dunes & Fem. & $0.47 \pm 0.11^{\mathrm{a}}$ & $0.23 \pm 0.04^{\mathrm{a}}$ & $1.40 \pm 0.02^{\mathrm{a}}$ & $0.26 \pm 0.005^{\mathrm{a}}$ \\
& Male & $0.46 \pm 0.05^{\mathrm{a}}$ & $0.29 \pm 0.02^{\mathrm{a}}$ & $1.36 \pm 0.03^{\mathrm{a}}$ & $0.27 \pm 0.01^{\mathrm{a}}$ \\
& Mean & $0.49 \pm 0.09^{\mathrm{A}}$ & $0.26 \pm 0.10^{\mathrm{B}}$ & $1.39 \pm 0.03^{\mathrm{B}}$ & $0.26 \pm 0.01^{\mathrm{A}}$ \\
\hline
\end{tabular}

Note: Fem., female A. horridus plants; Cont., control (inter-shrub open areas); SM, soil moisture; OM, organic matter; BD, bulk density; WHC, water-holding capacity. Different lowercase letters within a column indicate significance among different locations at $P<0.05$ level. Different uppercase letters within a column indicate significance among different sites at $P<0.05$ level. Mean \pm SD.

\subsection{Total numbers and tropic group of soil free-living nematodes}

Density of soil free-living nematodes at different sites fluctuated from 0 to 1585 individuals $/ 100 \mathrm{~g}$ dry soil (Fig. 1). The maximal density of soil free-living nematodes was found at FE sand dunes, i.e., 1585 individuals $/ 100 \mathrm{~g}$ dry soil in the sample collected beneath the male plants. At Delta, densities of soil free-living nematodes were low, reaching 119 and 124 individuals/100 $\mathrm{g}$ dry soil in the samples beneath the female and male A. horridus plants, respectively (Fig. 1), which was significant lower than those of the other two sites $(P<0.001)$. Densities of soil free-living nematodes were not significant at control among three sites. Similarly, no significant difference was found between male and female A. horridus plants, demonstrating no significant relationship between soil free-living nematodes abundance and plant gender.

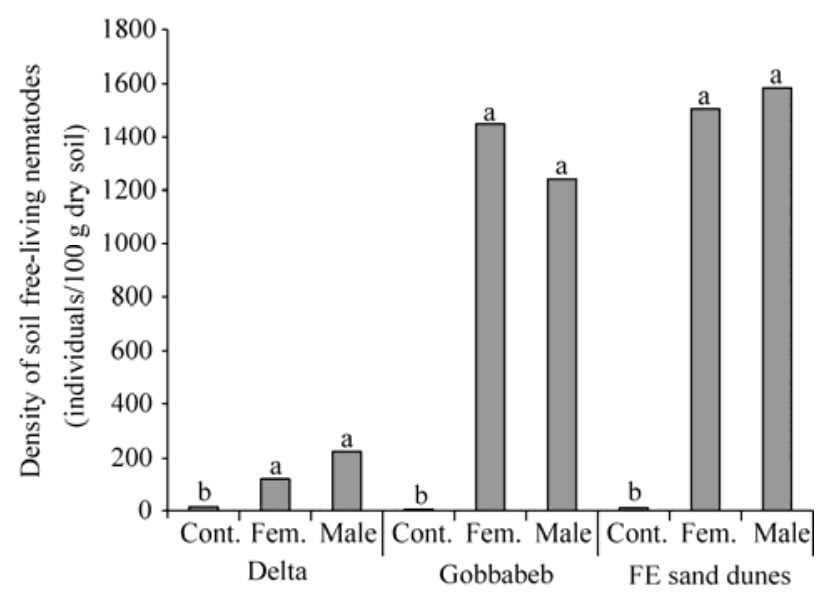

Fig. 1 Density of soil free-living nematodes at different sites (Delta, Gobabeb and Far East (FE) sand dunes) and locations. Fem., female A. horridus plants; Cont., control (inter-shrub open areas). Different lowercase letters indicate significant differences among three locations at $P<0.05$ level.

A total of 6915 quality-filtered sequences were obtained and clustered into 348 OTUs at $97 \%$ similarity. We calculated relative abundances of metazoa, fungi, algae and protista groups based on the 348 OTUs. At control location of FE sand dunes, the highest relative abundance was Protista (Fig. 2). The Protista kingdom was represented by Alveolata, Discoba and Rhizaria phyla, in which Discoba is known to be adapted to saline habitats. Algae, known to be a diverse group of 
photosynthetic organisms, represented by Chloroplastida and Stramenopiles-Chrysophyta at a relatively low abundance of $0.3 \%$ to a maximum abundance of $23.0 \%$ at Delta beneath the male $A$. horridus plants. Fungi were represented by Ascomycota and Basidiomycota, with relatively low abundances ranging from $0.2 \%$ to $46.0 \%$ at Gobabeb. In general, a significant variation among different eukaryotic organisms was found at different sites and locations (Fig. 2).

We found a total of 236 soil free-living nematodes based on the 348 OTUs. Low abundance OTUs (those containing less than $0.05 \%$ of total reads) were filtered out. Due to broad distribution of sequences among taxa, we selected representative sequence at a $95 \%$ similarity level from each OUT (Table 2). The overlap percentage of soil free-living nematodes among gender and control was shown in Table 2. As a result, a total of 67 groups, including 64 species, 2 genera and 1 family were identified (Table 3 ).

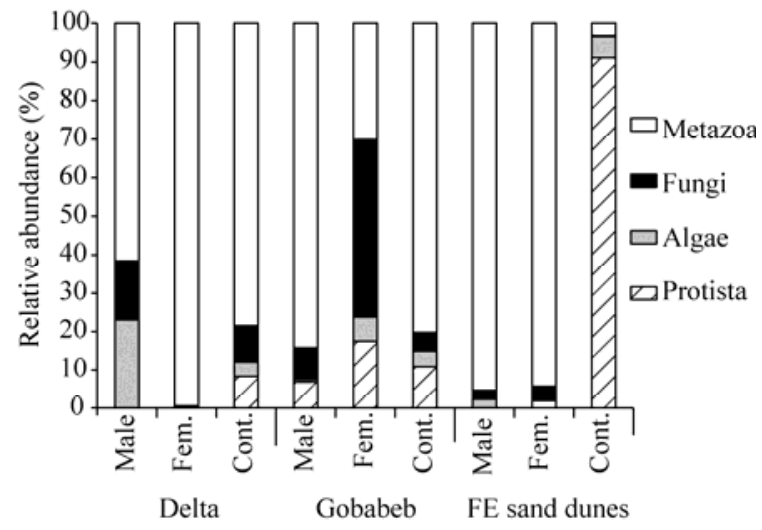

Fig. 2 Relative abundances of metazoa, fungi, algae and protista groups at different sites and locations based on 18S rDNA sequences. Fem., female A. horridus plants; Cont., control (inter-shrub open areas).

Table 2 Percentages of soil free-living nematodes at different sites and locations, and overlap percentage among plant gender and control locations

\begin{tabular}{cccc}
\hline Location & Delta $(\%)$ & Gobabeb (\%) & Far East sand dunes $(\%)$ \\
\hline Male & 17 & 50 & 0 \\
Female & 33 & 0 & 13 \\
Control & 33 & 0 & 37 \\
Male and female & 0 & 0 & 37 \\
Male and control & 0 & 25 & 0 \\
Female and control & 0 & 13 & 13 \\
Male, female and control & 17 & 13 & 0 \\
\hline
\end{tabular}

Unique species of soil free-living nematodes at Delta site was Ditylenchus destructor that was only found beneath the male $A$. horridus plants. The total number of soil free-living nematodes that was only occurred at Gobabeb was 46, of which 2 were found at control, 5 beneath the female A. horridus plants and 39 beneath the male A. horridus plants. Only 1 species, i.e., Ditylenchus sp. 5JH-2014 that was only occurred beneath the female A. horridus plants at FE sand dunes. The highest number of soil free-living nematodes was found beneath the male $A$. horridus plants at Gobabeb (64), followed by beneath the male A. horridus plants at FE sand dunes (24) and male A. horridus plants at Delta (17). No significant differences were found beneath the female $A$. horridus plants among three sites. A relatively low number of soil free-living nematodes were found at control, i.e., 14 at Delta, 22 at Gobabeb and 10 at FE sand dunes.

Among the 64 species of soil free-living nematodes, we found 18 representatives (Table 4) of different habitats, such as mammalian parasites, avian parasites, microphages, marine-living systems, pathogens and parasitic nematodes. 
Table 3 Taxa and trophic groups of soil free-living nematodes using 18S rDNA sequences and BLAST similarity analysis at different sites and locations

\begin{tabular}{|c|c|c|c|c|c|c|c|c|c|c|}
\hline \multirow{2}{*}{ Nematode species } & \multicolumn{3}{|c|}{ Delta } & \multicolumn{3}{|c|}{ Gobabeb } & \multicolumn{3}{|c|}{ Far East sand dunes } & \multirow{2}{*}{$\begin{array}{l}\text { Trophic } \\
\text { group }\end{array}$} \\
\hline & Cont. & Fem. & Male & Cont. & Fem. & Male & Cont. & Fem. & Male & \\
\hline Ditylenchus destructor & - & - & + & & & & & & & $\mathrm{FF}$ \\
\hline Number of species & - & - & 1 & & & & & & & \\
\hline Acrobeles ciliatus & & & & + & - & + & & & & $\mathrm{BF}$ \\
\hline Amblydorylaimus isokaryon & & & & - & - & + & & & & OP \\
\hline Anisakis simplex & & & & - & - & +++ & & & & AP \\
\hline Aphelenchoides (genus) & & & & - & - & + & & & & $\mathrm{FF}$ \\
\hline Aphelenchoides sp. US02 & & & & & + & + & & & & $\mathrm{FF}$ \\
\hline Brugia timori & & & & - & - & +++ & & & & TM \\
\hline Bursaphelenchus abruptus & & & & - & - & + & & & & $\mathrm{FF}$ \\
\hline Caenorhabditis elegans & & & & - & - & + & & & & $\mathrm{BF}$ \\
\hline Cephalobus cubaensis & & & & - & - & + & & & & $\mathrm{BF}$ \\
\hline Cooperia oncophora & & & & & - & + & & & & AP \\
\hline Echinocephalus overstreeti & & & & & - & ++ & & & & \\
\hline Enchodelus longispiculus & & & & - & - & + & & & & $\mathrm{PF}$ \\
\hline Enterobius vermicularis & & & & - & - & + & & & & AP \\
\hline Fergusobia sp. 281 & & & & & - & + & & & & $\mathrm{FF}$ \\
\hline Fergusobia sp. 469 & & & & & - & + & & & & FF \\
\hline Halalaimus sp. TCR 26 & & & & & - & + & & & & MS \\
\hline Halalaimus sp. TCR93 & & & & - & - & + & & & & MS \\
\hline Isolaimium multistriatum & & & & - & - & + & & & & MS \\
\hline Krefftascaris sharpiloi & & & & - & - & + & & & & AP \\
\hline Longidorus jonesi & & & & & + & +++ & & & & PP \\
\hline Meloidogyne javanica & & & & - & - & + & & & & PP \\
\hline Meloidogyne sp. Pak.P.R.m2 & & & & - & - & + & & & & PP \\
\hline Meloidogyne sp. VO-2014 & & & & - & - & + & & & & PP \\
\hline Panagrolaimidae sp. NK-2011b & & & & & - & + & & & & $\mathrm{BF}$ \\
\hline Parastrongyloides trichosuri & & & & - & + & +++ & & & & $\mathrm{OP}, \mathrm{AP}$ \\
\hline Passalurus ambiguus & & & & & - & +++ & & & & $\mathrm{OP}$ \\
\hline Pseudhalenchus minutus & & & & - & - & + & & & & \\
\hline Rhyssocolpus paradoxus & & & & - & + & & & & & OP \\
\hline Rhyssocolpus vinciguerrae & & & & & - & + & & & & OP \\
\hline Robustodorus megadorus & & & & & - & + & & & & \\
\hline Romanomermis culicivorax & & & & + & + & + & & & & \\
\hline Schistonchus caprifici & & & & - & - & + & & & & PP \\
\hline Steinernema feltiae & & & & - & - & + & & & & PI \\
\hline Steinernema sp. T51 & & & & & - & + & & & & PI \\
\hline Syphacia muris & & & & - & - & + & & & & \\
\hline Tricoma sp. 2 CYC-2009 & & & & - & - & + & & & & \\
\hline Trophotylenchulus sp. TSH-2009 & & & & - & - & + & & & & \\
\hline Xiphinema krugi & & & & - & - & ++ & & & & \\
\hline Xiphinema setariae & & & & & - & +++ & & & & PP \\
\hline Number of species & & & & 2 & 5 & 39 & & & & PP \\
\hline Ditylenchus sp. 5 JH-2014 & & & & & & & - & + & - & FF \\
\hline Number of species & & & & & & & 0 & 1 & 0 & \\
\hline Acrobeles sp. & - & + & + & + & - & + & - & + & + & $\mathrm{BF}$ \\
\hline
\end{tabular}




\begin{tabular}{|c|c|c|c|c|c|c|c|c|c|c|}
\hline \multirow{3}{*}{ Nematode species } & \multicolumn{10}{|c|}{ Continued } \\
\hline & \multicolumn{3}{|c|}{ Delta } & \multicolumn{3}{|c|}{ Gobabeb } & \multicolumn{3}{|c|}{ Far East sand dunes } & \multirow{2}{*}{$\begin{array}{c}\text { Trophic } \\
\text { group }\end{array}$} \\
\hline & Cont. & Fem. & Male & Cont. & Fem. & Male & Cont. & Fem. & Male & \\
\hline Acrobeles sp. MA-2012 & + & + & + & + & + & + & + & - & + & $\mathrm{BF}$ \\
\hline Acrobeloides cf. buetschlii $1 \mathrm{JH}-2012$ & +++ & +++ & - & + & - & ++ & + & + & + & $\mathrm{BF}$ \\
\hline Acrobeloides maximus & +++ & +++ & + & +++ & - & +++ & - & + & ++ & $\mathrm{BF}$ \\
\hline Aphelenchus avenae & - & + & - & - & - & + & - & + & ++ & $\mathrm{FF}$ \\
\hline Aporcelaimellus sp. JH-2004 & + & + & + & ++ & +++ & + & + & + & + & \\
\hline Bursaphelenchus anatolius & - & + & - & - & + & ++ & - & + & + & FF \\
\hline Bursaphelenchus penai & + & + & - & + & + & + & - & + & + & $\mathrm{FF}$ \\
\hline Cephalobidae (family) & + & ++ & - & +++ & +++ & +++ & + & +++ & +++ & $\mathrm{BF}$ \\
\hline Cylicostephanus goldi & + & - & - & + & + & + & +++ & - & + & AP \\
\hline Deladenus proximus & - & + & - & + & + & +++ & - & + & + & PW \\
\hline Haemonchus placei & ++ & + & + & +++ & +++ & +++ & +++ & + & + & PPR \\
\hline Hexamermis albicans & + & + & + & + & + & + & + & - & - & EA \\
\hline Hexatylus sp. 1 JH-2014 & - & + & - & + & + & + & - & + & + & $\mathrm{FF}$ \\
\hline Malenchus pressulus & - & + & + & - & + & + & - & + & + & PPR \\
\hline Meloidogyne incognita & - & - & + & - & - & + & - & + & + & PP \\
\hline Panagrolaimus paetzoldi & - & - & + & - & - & ++ & - & + & + & $\mathrm{BF}$ \\
\hline Panagrolaimus sp. AS01 & + & +++ & +++ & ++ & +++ & +++ & + & +++ & +++ & $\mathrm{BF}$ \\
\hline Panagrolaimus sp. AS03 & + & +++ & +++ & - & - & + & - & + & + & $\mathrm{BF}$ \\
\hline Panagrolaimus sp. SN103 & - & + & ++ & + & + & + & - & + & + & $\mathrm{BF}$ \\
\hline Paratylenchus goldeni PP & +++ & +++ & + & +++ & + & +++ & + & ++ & ++ & PP \\
\hline Paratylenchus labiosus & - & + & - & - & - & + & - & + & + & PP \\
\hline Turbatrix aceti & - & - & + & + & + & + & - & + & + & AP \\
\hline Tylenchulus semipenetrans & + & ++ & + & + & + & + & - & + & + & FF \\
\hline Uncultured Rhabdolaimus (genus) & + & - & + & ++ & + & +++ & +++ & + & + & $\mathrm{BF}$ \\
\hline Number of species & 14 & 20 & 16 & 20 & 18 & 25 & 10 & 22 & 24 & \\
\hline Total number of species & 14 & 20 & 17 & 22 & 23 & 64 & 10 & 23 & 24 & \\
\hline
\end{tabular}

Note: BF, bacteria-feeding; FF, fungi-feeding; PP, plant-parasite; AP, animal-parasite; PW, parasites on woodwasp; PPR, parasite/pathogenic of ruminants; EA, endoparasites in arthropods; MS, marine species; TM, transmitted by mosquitoes; PI, parasites on invertebrates; PF, feeds on mosses and lichens; Cont., control; Fem., female. +, appears in one replica; ++, appears in two replicas; +++, appears in all samples; -, no occurrence.

Of the 64 species of soil free-living nematodes, we identified feeding behavior of 58 species, i.e., 15 bacteria-feeding (BF) species, 12 fungi-feeding (FF) species, 10 plant-parasite (FP) species, 5 omnivorous-predator species, 8 animal-parasite (AP) species, 5 invertebrate-parasite (PI) species and 3 non-free-living nematodes, known as marine species (MS). One species, Enchodelus longi spicules that feeds on mosses and lichens (PF), might belong to plant feeding trophic group (Table 3).

\subsection{Relative abundance of genera of soil free-living nematodes and Venn diagram}

The results of relative abundance of genera of soil free-living nematodes (Fig. 3) showed a broad diversity, especially the relative abundance of Panroglimus genera that showed a higher percentage beneath the male and female plants at three sites.

A Venn diagram can be used to illustrate similarity and dissimilarity of soil free-living nematodes at each locations and possible relationships in plant gender. In three sets of circles for each gender and control at each site, we can see intersection or overlap of the three circles (Fig. 4). At Gobabeb and FE sand dunes, we found a total of 8 groups of soil free-living nematodes $(100 \%)$, while only 6 groups were found at Delta (Fig. 4). This result could be attributed to the effect of abiotic stress, i.e., high salinity in the soil of Delta (data not shown). 
Table 4 Family and habitat of these species of soil free-living nematodes in this study

\begin{tabular}{|c|c|c|c|}
\hline Species/genus & Family & Habitat & Reference \\
\hline Alaninema & Aphrophridae & Intestinal parasites in slugs & Ivanova et al. (2013) \\
\hline Amblydorylamus & Dorylaimidae & Nematode from Antarctica & Elshishka et al. (2015) \\
\hline Brugia-B. malayi & Filariidae & Present only in Southeast Asia & Triteeraprapab et al. (2001) \\
\hline Bursaphelenchus & Parasitaphelenchidae & Obligate mycrophages & Ryss et al. (2005) \\
\hline Cooperia & Cooperiidae & Intestinal parasites in cattle & Dorny et al. (1997) \\
\hline Cylicostephanus-C. goldi & Strongylidae & Intestinal parasites of horses & Bucknell et al. (1995) \\
\hline Deladnus & Neotylenchidae & Parasitic nematodes & Bedding (2009) \\
\hline Deladenus siricidicola & Neotylenchidae & Biological control agent of woodwasp & Bedding (2009) \\
\hline Dicelis & Drilonematoidea & Parasitic earthworm & Spiridonov (1992) \\
\hline Drasico nemoralis & & Endemic earthworm from far East Russia & Ivanova et al. (2014) \\
\hline Enerobius & Oxyuridae & Intestinal parasite in humans & Brown (2006) \\
\hline Epsilonema & Epsilonematidae & Marine species & $\begin{array}{l}\text { Gourbault and Decraemer } \\
\qquad(1994)\end{array}$ \\
\hline Eubosrichus & Desmodoridae & Marine species & Polz et al. (1999) \\
\hline Gongylongema & Gongylonematidae & Bird and mammal parasites & Soulsby (1982) \\
\hline Greeffiella & Desmoscolecoidea & Free-living marine nematode & $\begin{array}{l}\text { Abolafia and Pena-Santiago } \\
\text { (2016) }\end{array}$ \\
\hline Haemonchus & Trichostronylidae & Pathogenic nematodes of ruminants & Fleming et al. (2006) \\
\hline Halalaimus & Oxystominidae & Marine species & Turpeenniemi (1998) \\
\hline Halomonhystera & Monhysteridae & Marine species & Tchesunov et al. (2015) \\
\hline
\end{tabular}
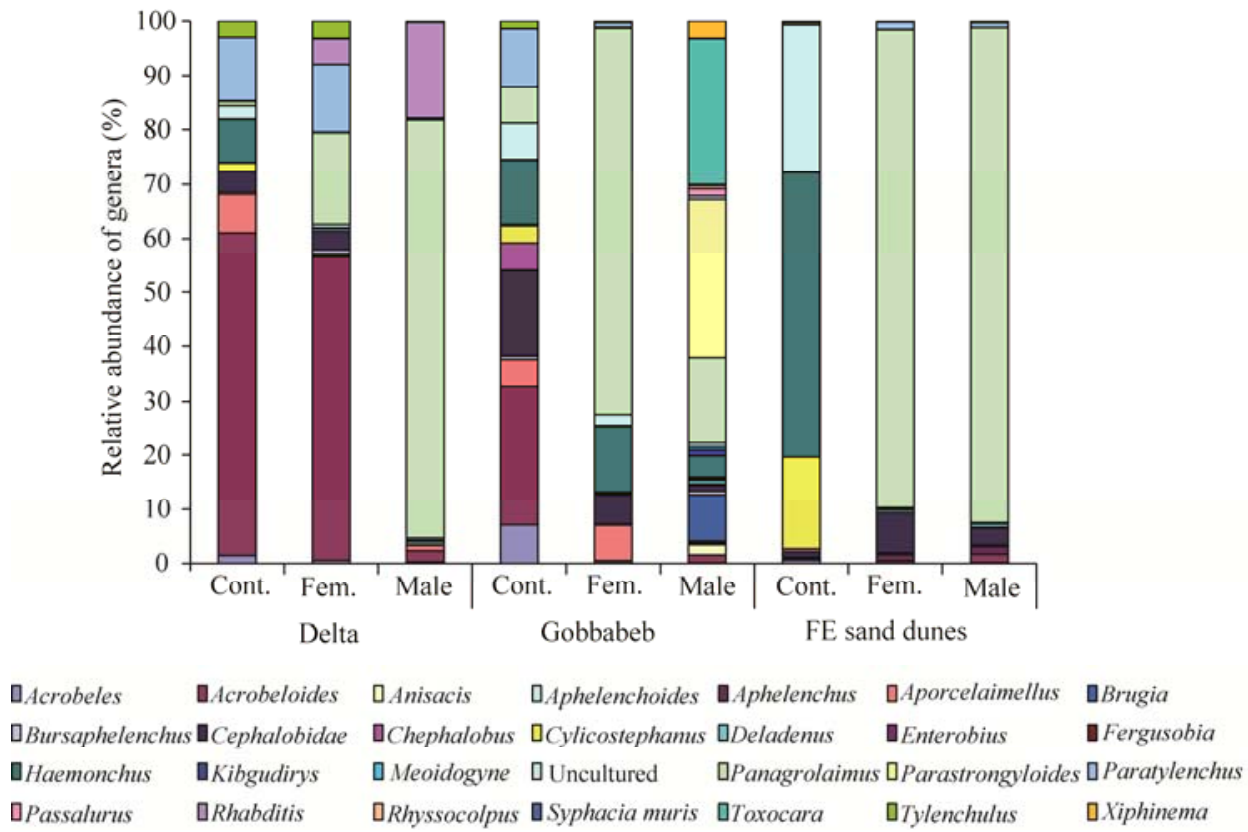

Fig. 3 Relative abundance of genera of soil free-living nematodes using 18S rDNA sequences and BLAST similarity analysis at three sites and locations

The Venn diagram also showed that at Delta, 50\% species of soil free-living nematodes occurred beneath the male and female A. horridus plants, while $33 \%$ species occurred in control, the remaining $17 \%$ species occurred in the union of $\mathrm{M} \cap \mathrm{F} \cap \mathrm{C}(\mathrm{M}$, male; F, female; $\mathrm{C}$, control; Fig. 4). At Gobabeb, 50\% species occurred beneath the male A. horridus plants and the remaining $50 \%$ species occurred in the unions of $\mathrm{M} \cap \mathrm{C}, \mathrm{F} \cap \mathrm{C}$ and $\mathrm{M} \cap \mathrm{F} \cap \mathrm{C}$. At $\mathrm{FE}$, only $13 \%$ species were 
found beneath the female $A$. horridus plants, and $37 \%$ species at control. The remaining $50 \%$ species were found in the unions of $\mathrm{M} \cap \mathrm{F}$ and $\mathrm{F} \cap \mathrm{C}$.
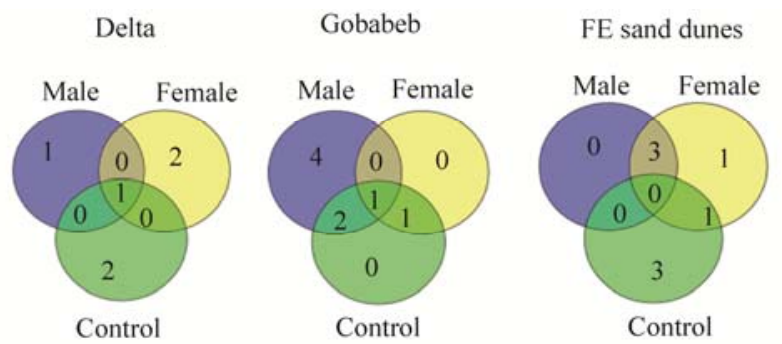

Fig. 4 Venn diagram showing similarity and dissimilarity of soil free-living nematodes at each locations and possible relationship in plant gender. Number of 0-4 means groups of soil free-living nematodes at the phylum level.

\subsection{Relative contributions of environmental factors to taxonomical composition}

Result of RDA showed that five environmental variables accounted for $33.0 \%$ of total variation (Table 5). Separate partial RDA showed that environmental variables differed in their influences on the composition of nematode community (Table 5; Figs. 5 and 6).

In the five environmental variables, only the effect of $\mathrm{OM}$ was significant $(P<0.05)$. Axis 1 $(F=7.05, P=0.012)$ showed a clear environmental gradient from Delta to FE sand dunes, which separated the community between Delta and FE sand dunes (Fig. 5). Axis 2 showed a clear environmental gradient from Gobabeb to Delta and FE sand dunes, which separated the community between the sites of Gobabeb and Delta+FE sand dunes.

In the five environmental variables, only the effect of $\mathrm{OM}$ was significant $(P<0.05)$. Axis 1 $(F=7.05, P=0.012)$ showed a clear environmental gradient from control to male, thus separating the community between control and male locations (Fig. 6).

Table 5 Redundancy analysis (RDA) of environmental variables based on sampling site and plant gender

\begin{tabular}{cccccc}
\hline Type & Variable & Initial conditional effect & MCR (\%) & $F$ & $P$ \\
\hline Sampling site & OM & 0.09 & 9 & 2.78 & $0.034^{*}$ \\
& WHC & 0.08 & 8 & 2.23 & 0.086 \\
& Cond & 0.08 & 8 & 2.23 & 0.078 \\
& pH & 0.07 & 7 & 2.20 & 0.114 \\
SM & 0.01 & 1 & 0.35 & 0.824 \\
Plant gender & Total & & 33 & 2.78 & $0.028^{*}$ \\
& OM & 0.09 & 9 & 2.23 & 0.092 \\
& WHC & 0.08 & 8 & 2.23 & 0.092 \\
& Cond & 0.08 & 8 & 7 & 2.20 \\
& pH & 0.07 & 1 & 0.35 & 0.104 \\
& SM & 0.01 & 33 & & 0.770 \\
\hline
\end{tabular}

Note: OM, organic matter; WHC, water-holding capacity; Cond, conductivity; SM, soil moisture; MCR, multivariate correlation ratio. ${ }^{*}$ indicates significance at $P<0.05$ level.

\section{Discussion}

Although soil free-living nematodes are known to be one of the most diverse metazoans in extreme environments, they have been poorly investigated, especially in hot deserts. The ability to use molecular tools allow us to spend less time in identifying soil free-living nematodes present in soils, and to improve our understanding of soil nematodes composition, dynamic and dispersion in extreme dry environments (Freckman et al., 1987; Barrett et al., 2005; Treonis and Wall, 2005). 


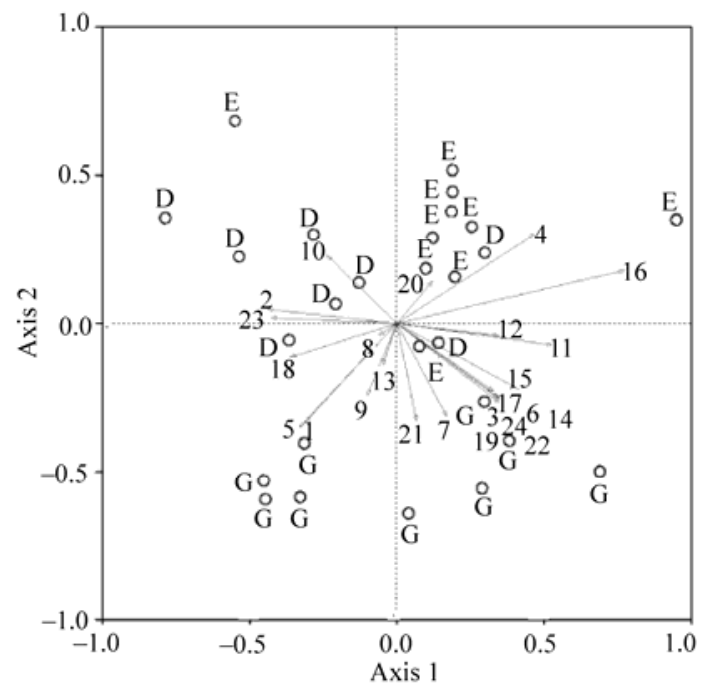

Fig. 5 Redundancy analysis (RDA) elucidating effects of sampling sites (D, Delta; E, Far East sand dunes; G, Gobabeb) on soil free-living nematodes. The number 1-23 means the replicates for sampling sites.

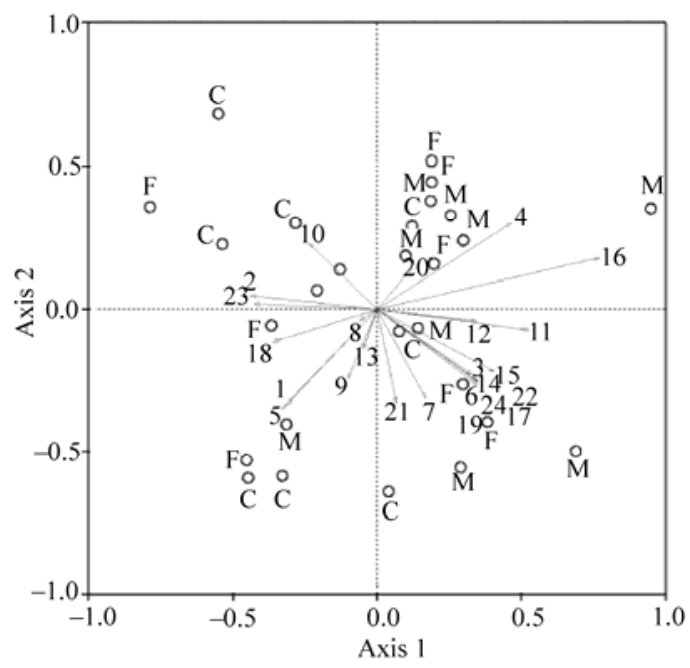

Fig. 6 Redundancy analysis (RDA) elucidating effects of plant gender and control (F, female; M, male; C, control) on soil free-living nematodes. The number 1-23 means the replicates for plant gender and control.

In the present study, we assessed the effect plant gender of A. horridus on soil free-living nematodes along a $150.0 \mathrm{~km}$ distance from the Atlantic Ocean to inland in the Namib Desert (Yeates, 2003). Sparse vegetation covered in the Namib Desert created a "fertile island" that acted as food-water shoppers for both the below-ground community and the above-ground biota. In general, abiotic components including SM, OM, BD and soil WHC are low in xeric desert ecosystems mainly due to the sandy soil substrate (Yu et al., 2016). Therefore, primary production of vegetation and soil properties will determine the consumers, for example, soil biota that obtained food resources from them, and soil biotic diversity is dependent on these food resources (Yeates, 1971; Coleman and Crossley, 1996; Whitford, 2002; Adl, 2003).

A significant difference in the total number of soil free-living nematodes was found along the $150.0 \mathrm{~km}$ distance, with a strong influence triggered by plants and SM, as presented by Pen-Mouratov et al. (2010) and Fitoussi et al. (2016). Bacterial-feeding soil free-living nematodes were found to comprise over $50 \%$ of the samples. Their short generation time along with high metabolic activities and relatively high reproduction rates, allowed them to fulfill their biological function in an extreme xeric environment by exploiting a short period of SM availability 
(Pen-Mouratov et al., 2010). These findings were similar to those of Freckman et al. (1987) and Steinberger et al. (1988, 1989). Changes in the composition and abundance of soil free-living nematodes were influenced by the availability of resources (e.g., OM) and adaptation to plant eco-physiological traits. A. horridus plants provided litter, food and shelter to the soil animals could enrich the biotic components with endoparasites during stopovers of mammals. Moreover, we found that soil free-living nematodes, according to the results of $18 \mathrm{~s}$ rDNA sequences, belonged to Brugia, Cooperia, Cylicostephanus, Deladenus, Enterobius and Haemonchus genera that were parasites on vertebrates, representing approximately $30 \%$ of the taxa, while the remaining $70 \%$ of the taxa were composed of $37 \%, 21 \%, 21 \%$ and $21 \%$ for BF, FF, PP and OP, respectively. These trophic visits by different animals might either be beneficial or cause harm in a long-term, due to the fact that animals might be carriers or even trajectories of diseases to other animals and even to humans (Jasmer et al., 2003; Holsback et al., 2013). Leung and Koprivnikar (2016) found that soil free-living nematodes contributed to the local economical loss as they parasitized plants and/or infested a wide range of animals, including humans.

The result of Venn analysis found that the interaction between both sampling locations and plant gender determined the percentage of soil free-living nematodes under each A. horridus plant (Fig. 4). Percentages of soil free-living nematodes accounted for $83 \%$ beneath the male, female plants and control at Delta, $50 \%$ beneath the female plants at Gobabeb, and $50 \%$ beneath the female plants and control at FE and dunes, respectively. According to Venn analysis, percentages of soil free-living nematodes at different sites varied: at Delta, $17 \%$ species occurred in the union of $\mathrm{M} \cap \mathrm{F} \cap \mathrm{C}$; at Gobabeb, $50 \%$ species occurred in the unions of $\mathrm{M} \cap \mathrm{C}, \mathrm{F} \cap \mathrm{C}, \mathrm{M} \cap \mathrm{F} \cap \mathrm{C}$; and $50 \%$ species at $\mathrm{FE}$ sand dunes could be explained by the unions of $\mathrm{M} \cap \mathrm{F}$ and $\mathrm{F} \cap \mathrm{C}$. This interplay elucidated the important effect of plant gender on soil free-living nematodes with the increase in aridity in environment. This result was similar to the findings of Beare et al. (1995), Ettema et al. (1998) and Yeates and Bongers (1999), who emphasized the importance of spatial scale and plant cover in a microhabitat to evaluate the diversity of nematodes.

\section{Conclusions}

The present study showed that soil free-living nematodes were strongly correlated with the changes in abiotic components. Moreover, the use of molecular tools had allowed us to increase the identification of soil free-living nematodes and endoparasites that were related to mammals in such xeric environment. The results from RDA analysis elucidated the importance of soil OM as one of the most important variables in determining density and trophic group composition of soil nematodes. These results also suggested that some other factors that were not considered in this study might contribute to the unexplained variation.

\section{Acknowledgements}

Special thanks to Ms. Sharon VICTOR for her useful comments and preparation of the manuscript for publication.

\section{References}

Abolafia J, Peña-Santiago R. 2016. Protorhabditis hortulana sp. n. (Rhabditida, Protorhabditidae) from southern Iberian Peninsula, one of the smallest free-living soil nematodes known, with a compendium of the genus. Zootaxa, 4144(3): $397-410$.

Adl S M. 2003. The Ecology of Soil Decomposition. Wallingford: CABI Publishing, 335.

Barrett J E, Virginia R A, Parsons A N, et al. 2005. Potential soil organic matter turnover in Taylor Valley, Antarctica. Arctic, Antarctic, and Alpine Research, 37(1): 108-117.

Beare M H, Coleman D C, Crossley D A J, et al. 1995. A hierarchical approach to evaluating the significance of soil biodiversity to biogeochemical cycling. In: Collins H P, Robertson G P, Klug M J. The Significance and Regulation of Soil Biodiversity. Dordrecht: Kluwer Academic Publishers, 5-22.

Bedding R A. 2009. Controlling the pine-killing woodwasp, Sirex noctilio, with nematodes. In: Hajek A E, Glare T R, O'Callaghan M. Use of Microbes for Control and Eradication of Invasive Arthropods. Netherlands: Springer, 213-235. 
Black C A. 1965. Methods of Soil Analysis: Part 1. Physical and Mineralogical Properties, Including Statistics of Measurement and Sampling. Madison: American Society of Agronomy, 1-1188.

Bongers T, Bongers M. 1998. Functional diversity of nematodes. Applied Soil Ecology, 10(3): 239-251.

Brown M D. 2006. Images in clinical medicine: Enterobius vermicularis. New England Journal of Medicine, 354(13): e12.

Bucknell D G, Gasser R B, Beveridge I. 1995. The prevalence and epidemiology of gastrointestinal parasites of horses in Victoria, Australia. International Journal for Parasitology, 25(6): 711-724.

Cairns E J. 1960. Methods in nematology. In: Sasser J N, Jenkins W R. Nematology, Fundamentals and Recent Advances with Emphasis on Plant Parasitic and Soil Forms. Chapel Hill: University of North Carolina Press, 33-84.

Caporaso J G, Bittinger K, Bushman F D, et al. 2010a. PyNAST: a flexible tool for aligning sequences to a template alignment. Bioinformatics, 26(2): 266-267.

Caporaso J G, Kuczynski J, Stombaugh J, et al. 2010b. QIIME allows analysis of high-throughput community sequencing data. Nature Methods, 7(5): 335-336.

Coleman D C, Crossley D A. 1996. Fundamentals of Soil Ecology. London: Academic Press, 205.

Crawford C S. 1981. Biology of Desert Invertebrates. Berlin, Heidelberg, New York: Springer-Verlag, 292.

Dorny P, Claerebout E, Vercruysse J, et al. 1997. The influence of a Cooperia oncophora priming on a concurrent challenge with Ostertagia ostertagi and C. oncophora in calves. Veterinary Parasitology, 70(1-3): 143-151.

Eckardt F D, Soderberg K, Coop L J, et al. 2013. The nature of moisture at Gobabeb, in the central Namib Desert. Journal of Arid Environments, 93: 7-19.

Elshishka M, Lazarova S, Radoslavov G, et al. 2015. New data on two remarkable Antarctic species Amblydorylaimus isokaryon (Loof, 1975) Andrassy, 1998 and Pararhyssocolpus paradoxus (Loof, 1975), gen. n., comb. n. (Nematoda, Dorylaimida). ZooKeys, (511): 25-68.

Ettema C H, Coleman D C, Vellidis G, et al. 1998. Spatiotemporal distributions of bacterivorous nematodes and soil resources in a restored riparian wetland. Ecology, 79(8): 2721-2734.

Evenari M E, Shanan L, Tadmor W. 1982. The Negev: The Challenge of a Desert ( $2^{\text {nd }}$ ed.). Cambridge: Harvard University Press, 345.

Fitoussi N, Pen-Mouratov S, Steinberger Y. 2016. Soil free-living nematodes as bio-indicators for assaying the invasive effect of the alien plant Heterotheca subaxillaris in a coastal dune ecosystem. Applied Soil Ecology, 102: 1-9.

Fleming S A, Craig T, Kaplan R M, et al. 2006. Anthelmintic resistance of gastrointestinal parasites in small ruminants. Journal of Veterinary Internal Medicine, 20(2): 435-444.

Freckman D W, Mankau R. 1977. Distribution and trophic structure of nematodes in desert soils. Ecological Bulletin, 25: 511-514.

Freckman D W, Whitford W G, Steinberger Y. 1987. Effect of irrigation on nematode population dynamics and activity in desert soils. Biology and Fertility of Soils, 3(1-2): 3-10.

Frossard A, Ramond J B, Seely M, et al. 2015. Water regime history drives responses of soil Namib Desert microbial communities to wetting events. Scientific Reports, 5: 12263.

Gourbault N, Decraemer W. 1994. Two new species of Epsilonema from South indopacific (Nemata, epsilonematidae). Journal of Nematology, 26(4): 384-391.

Holsback L, Cardoso M J L, Fagnani R, et al. 2013. Natural infection by endoparasites among free-living wild animals. Revista Brasileira De Parasitologia Veterinária, 22(2): 302-306.

Ivanova E S, Spiridonov S E, Clark W C, et al. 2013. Description and systematic affinity of Alaninema ngata n. sp. (Alaninematidae: Panagrolaimorpha) parasitising leaf-veined slugs (Athoracophoridae: Pulmonata) in New Zealand. Nematology, 15(7): 859-870.

Ivanova E S, Ganin G N, Spiridonov S E. 2014. A new genus and two new nematode species (Drilonematoidea: Ungellidae: Synoecneminae) parasitic in two morphs of Drawida ghilarovi Gates, endemic earthworm from the Russian Far East. Systematic Parasitology, 87(3): 231-248.

Jasmer D P, Goverse A, Smart G. 2003. Parasitic nematode interactions with mammals and plants. Annual Review of Phytopathology, 41: 245-270.

Laity J L. 2008. Deserts and Desert Environments. USA: Wiley-Blackwell Publications, 360.

Lambshead P J D. 2004. Marine nematode biodiversity. In: Chen Z X, Chen S Y, Dickson D W. Nematology: Advances and Perspectives, Vol. 1. Wallingford: CABI Publishing, 438-468.

Leung T L F, Koprivnikar J. 2016. Nematode parasite diversity in birds: the role of host ecology, life history and migration. Journal of Animal Ecology, 85(6): 1471-1480.

Levi T, Sherman C, Pen-Mouratov S, et al. 2012. Changes in soil free-living nematode communities and their trophic 
composition along a climatic gradient. Open Journal of Ecology, 2(2): 79-89.

Liu J L, Li F R, Liu C A, et al. 2012. Influences of shrub vegetation on distribution and diversity of a ground beetle community in a Gobi desert ecosystem. Biodiversity and Conservation, 21(10): 2601-2619.

Louw G N, Seely M K. 1982. Ecology of Desert Organisms. London and New York: Longman Group Ltd., 194.

Pen-Mouratov S, He X L, Steinberger Y. 2004. Spatial distribution and trophic diversity of nematode populations under Acacia raddiana along a temperature gradient in the Negev Desert ecosystem. Journal of Arid Environments, 56(2): 339-355.

Pen-Mouratov S, Hu C, Hindin E, et al. 2010. Effect of sand-dune slope orientation on soil free-living nematode abundance and diversity. Helminthologia, 47(3): 179-188.

Rodriguez-Zaragoza S, Mayzlish E, Steinberger Y. 2005. Seasonal changes in free-living amoeba species in the root canopy of Zygophyllum dumosum in the Negev Desert, Israel. Microbial Ecology, 49(1): 134-141.

Polz M F, Harbison C, Cavanaugh C M. 1999. Diversity and heterogeneity of epibiotic bacterial communities on the marine nematode Eubostrichus dianae. Applied and Environmental Microbiology, 65(9): 4271-4275.

Porazinska D L, Giblin-Davis R M, Faller L, et al. 2009. Evaluating high-throughput sequencing as a method for metagenomic analysis of nematode diversity. Molecular Ecology Resources, 9(6): 1439-1450.

Ryss A, Vieira P, Mota M, et al. 2005. A synopsis of the genus Bursaphelenchus Fuchs, 1937 (Aphelenchida: Parasitaphelenchidae) with keys to species. Nematology, 7(3): 393-458.

Seely M, Henschel J R, Hamilton W J. 2005. Long-term data show behavioural fog collection adaptations determine Namib Desert beetle abundance. South African Journal of Science, 101: 570-572.

Seely M K, Louw G N. 1980. First approximation of the effects of rainfall on the ecology and energetics of a Namib Desert dune ecosystem. Journal of Arid Environments, 3(1): 25-54.

Soulsby E. 1982. Helminths, Arthropods and Protozoa of Domesticated Animals. London: Bailliere and Tindall, 809.

Spiridonov S E. 1992. Mbanema nigeriense n. gen., n.sp. (Drilonematidae: Nematoda) from Eudrilus eugeniae (Eudrilidae: Oligochaeta) in Nigeria. Fundamental and Applied Nematology, 15(5): 443-447.

Steinberger Y, Orion D, Whitford W G. 1988. Population dynamics of nematodes in the Negev Desert soil. Pedobiologia, 31(3): 223-228.

Steinberger Y, Loboda I, Garner W. 1989. The influence of autumn dewfall on spatial and temporal distribution of nematodes in the desert ecosystem. Journal of Arid Environments, 16(2): 177-183.

Stomeo F, Makhalanyane T P, Valverde A, et al. 2012. Abiotic factors influence microbial diversity in permanently cold soil horizons of a maritime-associated Antarctic Dry Valley. FEMS Microbiology Ecology, 82(2): 326-340.

Tchesunov A V, Portnova D A, van Campenhout J. 2015. Description of two free-living nematode species of Halomonhystera disjuncta complex (Nematoda: Monhysterida) from two peculiar habitats in the sea. Helgoland Marine Research, 69: 57-85.

Treonis A M, Wall D H. 2005. Soil nematodes and desiccation survival in the extreme arid environment of the Antarctic dry valleys. Integrative \& Comparative Biology, 45(5): 741-750.

Triteeraprapab S, Karnjanopas K, Porksakorn C, et al. 2001. Lymphatic filariasis caused by Brugia malayi in an endemic area of Narathiwat Province, southern of Thailand. Journal of the Medical Association of Thailand, 84(Suppl. 1): 182-188.

Turpeenniemi T A. 1998. Ultrastructure of spermatozoa in the nematode Halalaimus dimorphus (Nemata: Oxystominidae). Journal of Nematology, 30(4): 391-403.

Wardle D A. 2002. Communities and Ecosystems: Linking the Aboveground and Belowground Components. Princeton: Princeton University Press, 408.

Whitford W G. 2002. Ecology of Desert Systems. New York, London: Academic Press, 343.

Yeates G W. 1971. Feeding types and feeding groups in plant and soil nematodes. Pedobiologia, 8: 173-179.

Yeates G W, Bongers T, De Goede R G M, et al. 1993. Feeding habits in soil nematode families and genera-an outline for soil ecologists. Journal of Nematology, 25(3): 315-331.

Yeates G W, King K L. 1997. Soil nematodes as indicators of the effect of management on grasslands in the New England Tablelands (NSW): Comparison of native and improved grasslands. Pedobiologia, 41: 526-536.

Yeates G W, Bongers T. 1999. Nematode diversity in agroecosystems. Agriculture, Ecosystems \& Environment, 74(1-3): $113-135$.

Yeates G W. 2003. Nematodes as soil indicators: functional and biodiversity aspects. Biology and Fertility of Soils, 37(4): 199-210.

Yilmaz P, Parfrey L W, Yarza P, et al. 2014. The SILVA and "All-species Living Tree Project (LTP)" taxonomic frameworks. Nucleic Acids Research, 42: 643-648.

Yu J, Guan P, Zhang X, et al. 2016. Biocrusts beneath replanted shrubs account for the enrichment of macro and micronutrients in semi-arid sandy land. Journal of Arid Environments, 128: 1-7. 